\title{
PELATIHAN PEMBUKUAN SEDERHANA BAGI PELAKU UMKM PANCUR BATU DI DESA BARU KECAMATAN PANCUR BATU
}

\author{
Chairia'), Jenni Veronika Br Ginting'), Polin Ramles'), Yolanda Sabrina1) \\ 1)Program Studi D-III Akuntansi, Institut Teknologi dan Bisnis Indonesia, Deli Serdang, Sumatera Utara, Indonesia \\ Corresponding author : Chairia \\ E-mail : chairialubis20@gmail.com
}

Diterima 17 November 2021, Direvisi 26 November 2021, Disetujui 27 November 2021

\begin{abstract}
ABSTRAK
Keberadaan UMKM memegang peranan penting dalam perekonomian, baik dalam menyerap tenaga kerja, menyumbang devisa maupun kontribusinya dalam menyumbang pendapatan daerah dalam bentuk pajak. Masalah yang dihadapi Usaha Mikro Kecil dan Menengah (UMKM) adalah kesulitan pemasaran, keterbatasan inovasi dan teknologi, khususnya keterbatasan menyusun pembukuan sederhana. Dengan adanya pelatihan pembukuan sederhana kepada para UMKM, memberikan kontribusi bagaimana menyusun pembukuan antara pemasukan dan pengeluaran, sehingga dapat mempermudah proses pencatatan arus kas dan kinerja yang diperoleh UMKM. Kegiatan pengabdian kepada masyarakat ini bertujuan agar pelaku usaha memahami dasar dan prosedur melakukan pencatatan dan pembukuan sederhana serta dapat membuat laporan keuangan.Metode yang dilakukan dalam PKM ini dengan workshop menggunakan alat bantu berupa laptop, smartphone, dan proyektor. Penyampaian materi dilakukan dengan ceramah, praktek langsung, tanya jawab dan diskusi. Pengabdian ini bertujuan memberikan pengetahuan dan keterampilan dasar untuk memberi motivasi dan semangat kepada pelaku UMKM untuk melakukan wirausaha, meningkatkan kreativitas dan inovasi para pelaku UMKM, dan memberi pengetahuan tentang pentingnya pencatatan transaksi keuangan melalui pembukuan sederhana. Berdasarkan pengamatan langsung, wawancara dan melakukan tanya jawab kepada para peserta selama kegiatan berlangsung, kegiatan pengabdian masyarakat ini memberikan hasil yaitu memberi motivasi dan semangat kepada pelaku UMKM untuk melakukan wirausaha, meningkatkan kreativitas dan inovasi para pelaku UMKM, dan memberi pengetahuan tentang pentingnya pencatatan transaksi keuangan melalui pembukuan sederhana.
\end{abstract}

Kata kunci: UMKM; pembukuan sederhana; wirausaha; pelaku usaha; ekonomi

\begin{abstract}
The existence of UMKMs plays an important role in the economy, both in absorbing labor, contributing to foreign exchange and contributing to regional income in the form of taxes. The problems faced by Micro, Small and Medium Enterprises (UMKMs) are marketing difficulties, limitations of innovation and technology, in particular the limitations of compiling simple bookkeeping. With the existence of simple bookkeeping training for UMKMs, contributing to how to arrange bookkeeping between income and expenditure, so as to facilitate the process of recording cash flow and performance obtained by UMKMs. This community service activity aims to make business actors understand the basics and procedures for simple recording and bookkeeping and can make financial reports. The method carried out in this training is with workshops using tools such as laptops, smartphones, and projectors. Submission of material is done by lecture, direct practice, question and answer and discussion. This service aims to provide basic knowledge and skills to motivate and encourage UMKMs people to do entrepreneurship, increase creativity and innovation for UMKMs people, and provide knowledge about the importance of recording financial transactions through simple bookkeeping. In virtue of our direct observations, interviews and conducting questions and answers to the participants during the activity, this projects gave results are providing motivation and enthusiasm for UMKMs people to do entrepreneurship, increasing creativity and innovation of UMKMs people, and providing knowledge about the importance of recording financial transactions through simple bookkeeping.
\end{abstract}

Keywords: UMKM; simple bookkeeping; entrepreneurs; business actors; economics

PENDAHULUAN

Keberadaan UMKM memegang

peranan penting dalam perekonomian, baik dalam menyerap tenaga kerja, menyumbang devisa maupun kontribusinya dalam 
menyumbang pendapatan daerah dalam bentuk pajak (Nurlida \& Sinuraya, 2020).

UMKM bersifat income gathering yaitu menaikkan pendapatan, dengan ciri-ciri sebagai berikut: merupakan usaha milik keluarga, menggunakan teknologi yang masih relatif sederhana, kurang memiliki akses permodalan (unbankable), dan tidak ada pemisahan modal usaha dengan kebutuhan pribadi (Lestiani, Maryam, \& Widayanti, 2020). UMKM perlu diarahkan untuk mendukung pencapaian sasaran penanggulangan kemiskinan dan pertumbuhan ekonomi. Upaya peningkatan UMKM yang berkaitan dengan misi penanggulangan kemiskinan dilaksanakan melalui perbaikan produktivitas dan nilai tambah produk khususnya bagi usaha mikro yang sebagian besar mencakup masyarakat berpendapatan rendah. Hasilnya diharapkan dapat meningkatkan pendapatan, serta perkembangan usahanya secara berkelanjutan (Hasibuan, Swibawa, Indriyati, \& Aeny, 2011). Masalah yang dihadapi Usaha Mikro Kecil dan Menengah (UMKM) adalah kesulitan pemasaran, keterbatasan inovasi dan teknologi, khususnya keterbatasan menyusun pembukuan sederhana (Rahmat \& Suryakancana, 2016). ITB Indonesia memberikan pelatihan bagi UMKM mengenai etika bisnis, pembukuan transaksi keuangan, pemasaran barang dan jasa, kemasan dan label produk.

Pembukuan transaksi keuangan adalah salah satu tugas penting dalam melakukan atau mencatat transaksi bisnis, seringkali pembukuan ini jarang dilakukan Usaha Mikro Kecil Menengah (UMKM) karena keterbatasan informasi di bidang akuntansi dan Usaha Mikro Kecil Menengah (UMKM) berfokus hanya pada bagaimana cara melakukan pemasaran (Juita, 2016).

Pengelola UMKM masih banyak yang belum sadar pentingnya akuntansi dalam perkembangan usaha. Sekecil apapun data keuangan yang dimiliki, harus dicatat dengan baik dan ada pembuktian melalui laporan keuangan. Melihat banyak UMKM yang pembukuannya masih sangat kurang bahkan tidak melakukan pembukuan, maka peran pemerintah dan lembaga-lembaga terkait akan sangat penting bagi UMKM untuk membantu memberikan pelatihan serta memberikan pemahaman tentang bagaimana pencatatan dan pelaporan keuangan yang baik (Sembiring \& Elisabeth, 2018).

Dengan adanya pelatihan pembukuan sederhana kepada para UMKM, memberikan kontribusi bagaimana menyusun pembukuan antara pemasukan dan pengeluaran, sehingga dapat mempermudah proses pencatatan arus kas dan kinerja yang diperoleh UMKM.

Dimasa pandemi Covid 19 saat ini banyak unit bisnis tumbang dengan berlakunya PSBB. Pemerintah DKI Jakarta memutuskan mengambil kebijkan tegas PSBB untuk menghambat dan menghemntikan penyebaran covid 19. Akibatnya terhenti sebagian besat aktivitas bisnis baik, perusahaan besar maupun perusahaan berskala kecil atau UMKM. Namun masih banyak UMKM yang bisa bertahan di masa Covid 19 ini (Arbi, 2020).

Pelaku UMKM yang menjadi sentra ekonomi terkecil di masyarakat inilah yang bisa membantu perekonomian di tengah-tengah masyarakat. Kualitas keberadaan UMKM harus ditingkatkan mulai dari kegiatan operasi sampai dengan bagaimana mempraktekkan pembukuan sederahana dengan tujuan tertib pembukuan dan penyajian laporan keuangan sesuai dengan standar akuntansi yang berkalu untuk UMKM (Limanseto, 2021).

Kegiatan PKM ini menjadi penting sebagai basis produksi, diseminasi, dan aplikasi ilmu pengetahuan. Kegiatan pengabdian kepada masyarakat ini bertujuan agar pelaku usaha memahami dasar dan prosedur melakukan pencatatan dan pembukuan sederhana serta dapat membuat laporan keuangan. Mayoritas penduduk Desa Baru kecamatan Pancur Batu berusaha sebagai pekerja, namun sebagian lagi dari penduduk adalah memuka usaha kecil-kecilan dibidang kuliner, pakaian, dan lain-lain. Namun bertambahnya pelaku usaha tidak diiringi dengan perkembangan aspek finansial. Ini dikarenakan, minimnya motivasi dari pelaku usaha dan kurangnya kemampuan pelaku usaha dalam mengelola keuangan usaha mereka (Kesuma, Nurullah, \& Meirawati, 2020).

Peserta kegiatan PKM ini merupakan pelaku-pelaku UMKM di Desa Baru kecamatan Pancur Batu. Kegiatan ini mengikuti protocol kesehatan dengan menjaga jarak, menggunakan masker, menyediakan tempat mencuci tangan di lokasi kegiatan. Kegiatan PKM dilaksanakan pada hari Kamis, 28 Oktober 2021 di Kantor Desa Baru Baru kecamatan Pancur Batu. Jumlah peserta kegiatan sebanyak 25 orang dan pelaksana kegiatan berjumlah 6 orang yang terdiri dari 4 orang dosen tetap dan 2 orang mahasiswa D-III Akuntansi Institut Teknologi dan Bisnis Indonesia.

Dari pemaparan di atas, kami berniat menyelenggarakan "Pelatihan Pembukuan Sederhana Bagi Pelaku Umkm Pancur Batu Di Desa Baru Kecamatan Pancur Batu". Dengan adanya kegiatan ini bertujuan agar pelaku UMKM dapat memaksimalkan meningkatkan 
perekonomian pelaku UMKM dan melakukan strategi pemasaran.

\section{METODE}

Metode yang dilakukan dalam PKM ini dengan workshop menggunakan alat bantu berupa laptop, smartphone, dan proyektor. Penyampaian materi dilakukan dengan ceramah, praktek langsung, tanya jawab dan diskusi. Prosedur dan tahapan-tahapan dalam kegiatan ini meliputi : 1) studi pendahuluan; 2) pelatihan; 3) evaluasi; dan 4) pelaporan (kemendikbud, 2021). Detail tahapan seperti gambar di bawah ini :

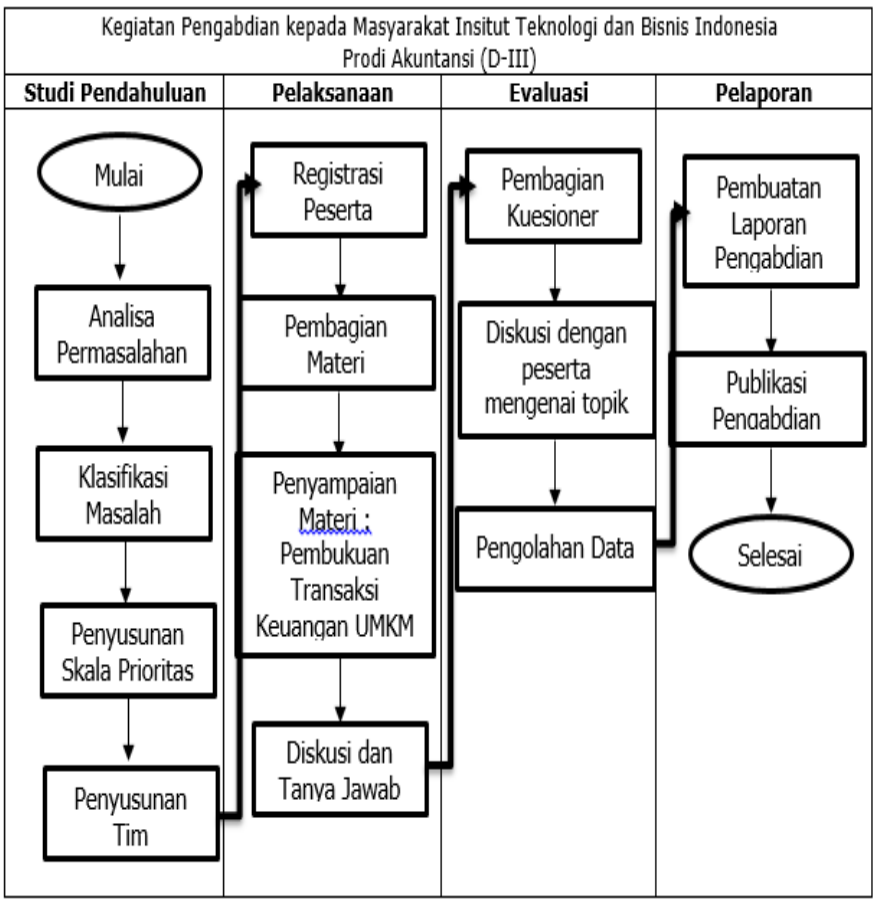

Gambar 1. Kerangka Pemecahan Masalah Sumber : Data Diolah (Penulis)

Perincian kegiatan di masing-masing tahapan diuraikan sebagai berikut:

1. Studi Pendahuluan

Pada tahapan studi pendahuluan dilakukan kegiatan-kegiatan sebagai berikut:

a) Melakukan analisa permasalahan yang dihadapi oleh pelaku UMKM Pancur Desa Baru kecamatan Pancur Batu yang nantinya akan menjadi peserta pelatihan.

b) Melakukan klasifikasi permasalahan dengan potensi yang dimiliki oleh dosen dan mahasiswa Akuntansi (D-III) Institut Teknologi dan Bisnis Indonesia.

c) Menyusun skala prioritas yang dapat langsung ditindaklanjuti dengan kegiatan PKM dan ketersediaan sumber daya.

d) Membentuk tim PKM da menyusun rencana kerja, uraian kerja berdasarkan kepakaran yang dimiliki, membuat instrument oelaksanaan kegiatan beserta proposal kegiatan, dan melakukan pembekalan tim PKM dalam hal pelaksanaan teknis.

\section{Pelaksanaan}

Pada tahapan pelaksanaan dilakukan kegiatankegiatan sebagai berikut:

a) Registrasi peserta oleh pelaku UMKM Pancur Desa Baru kecamatan Pancur Batu.

b) Pembagian materi dalam bentuk softcopy dan hardcopy kepada peserta.

c) Penyampaian materi PKM.

d) Tanya jawab, diskusi dan praktek langsung tentang materi yang disampaikan.

\section{Evaluasi}

Pelaksanaan evaluasi kegiatan digunakan untuk mendapatkan umpan balik dari kegiatan yang sudah terlaksana dan tindak lanjut untuk kegiatan PKM berikutnya. Pada tahap ini dilakukan pembagian kuesioner dan diskusi topik PKM lanjutan dengan peserta. Hasil dari evaluasi juga akan dijadikan bahan dalam menyusun laporan pelaksanaan PKM.

\section{Pelaporan}

Pada tahap ini dilakukan penyusunan laporan dan publikasi hasil PKM sebagai pertanggungjawaban pelaksanaan PKM kepada pihak-pihak yang berkepentingan.

\section{HASIL DAN PEMBAHASAN Hasil}

Pengabdian ini bertujuan memberikan pengetahuan dan keterampilan dasar untuk memberi motivasi dan semangat kepada pelaku UMKM untuk melakukan wirausaha, meningkatkan kreativitas dan inovasi para pelaku UMKM, dan memberi pengetahuan tentang pentingnya pencatatan transaksi keuangan melalui pembukuan sederhana. Berdasarkan pengamatan langsung, wawancara dan melakukan Tanya jawab kepada para peserta selama kegiatan berlangsung, kegiatan pengabdian masyarakat ini memberikan hasil sebagai berikut:

a) Memberi motivasi dan semangat kepada pelaku UMKM untuk melakukan wirausaha.

b) Meningkatkan kreativitas dan inovasi para pelaku UMKM.

c) Memberi pengetahuan tentang pentingnya pencatatan transaksi keuangan melalui pembukuan sederhana.

\section{Pembahasan}

Dalam kegiatan ini disediakan kuesioner yang diberikan kepada semua peserta. Kuesioner yang dibagikan sebanyak 25 lembar yang terdiri dari 8 (delapan) pertanyaan pilihan dan 2 (dua) pertanyaan 
essay, dan semuanya sudah di isi dan dikembalikan oleh peserta. Pembagian kuesioner ini digunakan untuk mengetahui tanggapan peserta terhadap pelatihan dan sebagai masukan bagi penyelenggara kegiatan untuk lebih baik lagi kedepannya.

Adapun pertanyaan yang diberikan kepada peserta kegiatan seperti tabel berikut ini:

Tabel 1. Daftar Pertanyaan pada Kuesioner

\begin{tabular}{clll}
\hline No. & \multicolumn{3}{c}{ PERTANYAAN (P) } \\
\hline 1 & $\begin{array}{l}\text { Materi Yang Disampaikan } \\
\text { Kegiatan }\end{array}$ & Dalam \\
\hline 2 & $\begin{array}{l}\text { Respon Terhadap Materi } \\
\text { Disampaikan }\end{array}$ & Yang \\
\hline 3 & $\begin{array}{l}\text { Hubungan Materi Yang Disampaikan } \\
\text { Dengan Kebutuhan }\end{array}$ & \\
\hline 4 & Pemateri Dan Teknik Penyajian \\
\hline 5 & $\begin{array}{l}\text { Waktu Yang Dipergunakan Dalam } \\
\text { Menyampaikan Materi }\end{array}$ & \\
\hline 6 & Kejelasan Materi Kegiatan & \\
\hline 7 & Minat Terhadap Kegiatan & \\
\hline 8 & Kepuasan Terhadap Kegiatan & \\
\hline
\end{tabular}

Rekapitulasi hasil tanggapan para peserta kegiatan ini dijabarkan seperti tabel berikut ini:

Tabel 2. Rekapitulasi Hasil Tanggapan Para Peserta

\begin{tabular}{|c|c|c|c|c|c|c|c|c|c|c|}
\hline \multirow{2}{*}{ No. } & \multirow{2}{*}{ NAMA PESERTA } & \multicolumn{8}{|c|}{ PERTANYAAN (P) } & \multirow{2}{*}{ TOTAL } \\
\hline & & P1 & P2 & P3 & P4 & P5 & P6 & P7 & p8 & \\
\hline 1 & Sri Ayu & 5 & 4 & 3 & 5 & 4 & 4 & 5 & 5 & 35 \\
\hline 2 & Mujianto & 5 & 4 & 4 & 3 & 5 & 5 & 5 & 5 & 36 \\
\hline 3 & Darlin Siburian & 5 & 4 & 5 & 4 & 3 & 4 & 5 & 5 & 35 \\
\hline 4 & Sulastri & 5 & 4 & 5 & 5 & 5 & 4 & 5 & 5 & 38 \\
\hline 5 & Carolina & 4 & 5 & 5 & 4 & 3 & 4 & 4 & 4 & 33 \\
\hline 6 & Mirna Uriska Sitepu & 4 & 4 & 4 & 5 & $\frac{4}{4}$ & 4 & 3 & $\left.\frac{7}{4}+x-1\right) x$ & 32 \\
\hline 7 & Asri Alfi Zahara & 4 & 3 & 4 & 4 & 4 & 4 & 4 & 3 & 30 \\
\hline 8 & Teguh Pernando Barus & 4 & 4 & 3 & 4 & 4 & 3 & 4 & 5 & 31 \\
\hline 9 & Bahagia & 4 & 4 & 3 & 3 & 5 & 4 & 4 & 4 & 31 \\
\hline 10 & Samsul & 4 & 4 & 4 & 3 & 5 & 5 & 5 & 5 & 35 \\
\hline 11 & Budiman Berutu & 4 & 3 & 4 & 5 & 5 & 4 & 5 & 4 & 34 \\
\hline 12 & Gita Asmarani & 5 & 4 & 5 & 5 & 4 & 4 & 4 & 3 & 34 \\
\hline 13 & Sebayang & 3 & 4 & 5 & 5 & 5 & 4 & 3 & 5 & 34 \\
\hline 14 & Aliana Handayani & 4 & 4 & 5 & 3 & 5 & 5 & 5 & 4 & 35 \\
\hline 15 & Nur Indahyani & 4 & 4 & 4 & 3 & 3 & 4 & 4 & 5 & 31 \\
\hline 16 & $\begin{array}{l}\text { Ribka Natalia } \\
\text { Panggabean }\end{array}$ & 5 & 4 & 4 & 5 & 4 & 4 & 5 & 5 & 36 \\
\hline 17 & Henny $\mathrm{Br}$ Ginting & 4 & 4 & 5 & 5 & 4 & 5 & 5 & 5 & 37 \\
\hline 18 & Nova Br Ginting & 5 & 4 & 4 & 3 & 4 & 3 & 4 & 5 & 32 \\
\hline 19 & Reni Siburian & 5 & 5 & 5 & 5 & 5 & 5 & 5 & 4 & 39 \\
\hline 20 & Anton Barus & 5 & 5 & 5 & 5 & 5 & 5 & 5 & 5 & 40 \\
\hline 21 & Menda Br Ginting & 5 & 4 & 4 & 5 & 5 & 5 & 5 & 5 & 38 \\
\hline 22 & Agusplu Surbakti & 5 & 5 & 5 & 5 & 5 & 5 & 5 & 5 & 40 \\
\hline 23 & Sri Br Purba & 5 & 5 & 5 & 4 & 5 & 5 & 4 & 4 & 37 \\
\hline 24 & Indah Girsang & 5 & 5 & 5 & 4 & 5 & 5 & 5 & 5 & 39 \\
\hline 25 & Lea Br Ginting & 5 & 4 & 4 & 5 & 5 & 5 & 4 & 4 & 36 \\
\hline & TOTAL & 113 & 104 & 109 & 107 & 111 & 109 & 112 & 113 & 878 \\
\hline
\end{tabular}

Keterangan/Skala Penilaian:

$5=$ Sangat Baik

$4=$ Baik

$3=$ Cukup

$2=$ Kurang Baik

$1=$ Sangat Kurang Baik

Penjelasan lebih lanjut tentang tanggapan peserta kegiatan pada setiap pertanyaan yang diberikan adalah sebagai berikut:
1. Materi Yang Disampaikan Dalam Kegiatan

Pertanyaan ini diberikan untuk mengetahui bagaimana pendapat peserta terhadap materi yang disampaikan dalam kegiatan. Adapun hasil tanggapan dari peserta seperti gambar berikut.

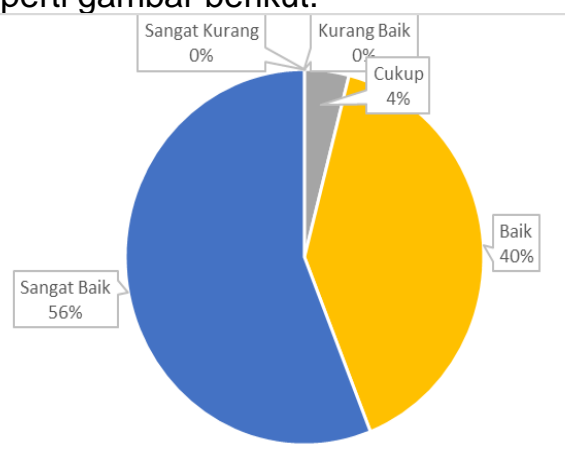

Gambar 2. Tanggapan Peserta Terhadap Materi Yang Disampaikan Dalam Kegiatan Sumber : Data Diolah (Penulis)

Berdasarkan gambar di atas, $56 \%$ peserta berpendapat bahwa materi yang disampaikan dalam kegiatan sangat baik, $40 \%$ peserta berpendapat baik, $4 \%$ peserta berpendapat cukup, dan tidak ada yang berpendapat bahwa materi yang disampaikan dalam kegiatan kurang baik dan sangat kurang baik. Dari gambar di atas dapat disimpulkan bahwa mayoritas peserta berpendapat bahwa materi yang disampaikan dalam kegiatan sangat baik.

\section{Respon Terhadap Materi Yang Disampaikan}

Pertanyaan ini diberikan untuk mengetahui bagaimana pendapat peserta terhadap respon terhadap materi yang disampaikan dalam kegiatan. Adapun hasil tanggapan dari peserta seperti gambar berikut.

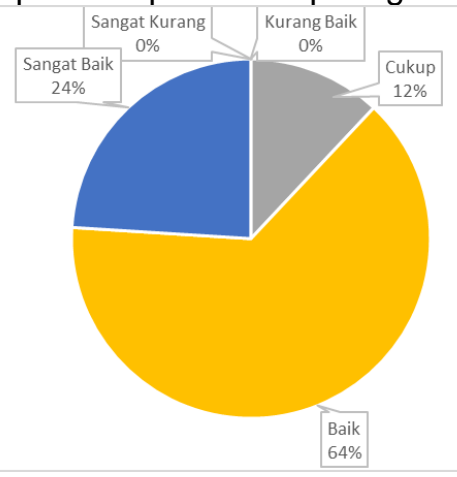

Gambar 3. Tanggapan Peserta Terhadap Respon Terhadap Materi Yang Disampaikan Sumber : Data Diolah (Penulis)

Berdasarkan gambar di atas, $64 \%$ peserta berpendapat bahwa respon terhadap materi yang disampaikan dalam kegiatan baik, $24 \%$ peserta berpendapat sangat baik, 12\% peserta berpendapat cukup, dan tidak ada yang berpendapat bahwa respon terhadap materi yang disampaikan dalam kegiatan kurang baik dan sangat kurang baik. Dari 
gambar di atas dapat disimpulkan bahwa mayoritas peserta berpendapat bahwa respon terhadap materi yang disampaikan dalam kegiatan baik.

\section{Hubungan Materi Yang Disampaikan Dengan Kebutuhan}

Pertanyaan ini diberikan untuk mengetahui bagaimana pendapat peserta terhadap hubungan materi yang disampaikan dengan kebutuhan dalam kegiatan. Adapun hasil tanggapan dari peserta seperti gambar berikut.

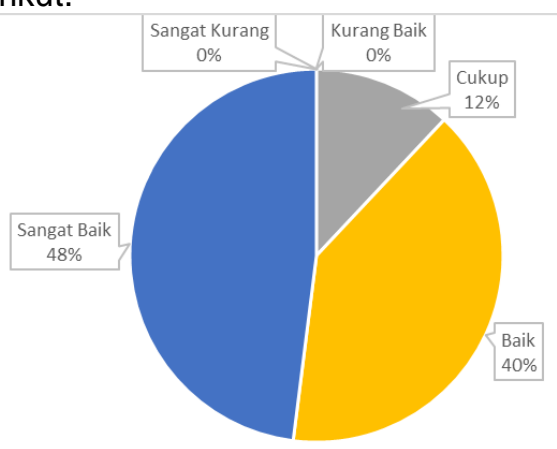

Gambar 4. Tanggapan Peserta Terhadap Hubungan Materi Yang Disampaikan Dengan Kebutuhan

Sumber : Data Diolah (Penulis)

Berdasarkan gambar di atas, $48 \%$ peserta berpendapat bahwa hubungan materi yang disampaikan dengan kebutuhan dalam kegiatan sangat baik, $40 \%$ peserta berpendapat baik, $12 \%$ peserta berpendapat cukup, dan tidak ada yang berpendapat bahwa hubungan materi yang disampaikan dengan kebutuhan dalam kegiatan kurang baik dan sangat kurang baik. Dari gambar di atas dapat disimpulkan bahwa mayoritas peserta berpendapat bahwa hubungan materi yang disampaikan dengan kebutuhan dalam kegiatan sangat baik.

\section{Pemateri dan Teknik Penyajian}

Pertanyaan ini diberikan untuk mengetahui bagaimana pendapat peserta terhadap pemateri dan teknik penyajian dalam kegiatan. Adapun hasil tanggapan dari peserta seperti gambar berikut.

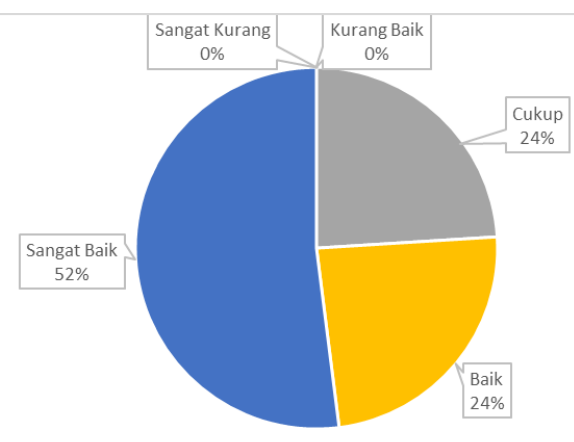

Gambar 5. Tanggapan Peserta Terhadap Pemateri dan Teknik Penyajian Sumber : Data Diolah (Penulis)

Berdasarkan gambar di atas, $52 \%$ peserta berpendapat bahwa pemateri dan teknik penyajian dalam kegiatan sangat baik, $24 \%$ peserta berpendapat baik dan cukup, dan tidak ada yang berpendapat bahwa pemateri dan teknik penyajian dalam kegiatan kurang baik dan sangat kurang baik. Dari gambar di atas dapat disimpulkan bahwa mayoritas peserta berpendapat bahwa pemateri dan teknik penyajian dalam kegiatan sangat baik.

\section{Waktu yang Dipergunakan dalam} Menyampaikan Materi

Pertanyaan ini diberikan untuk mengetahui bagaimana pendapat peserta terhadap waktu yang dipergunakan dalam menyampaikan materi dalam kegiatan. Adapun hasil tanggapan dari peserta seperti gambar berikut.

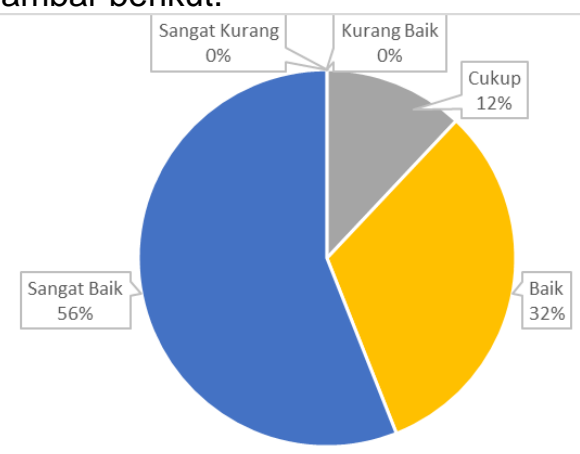

Gambar 6. Tanggapan Peserta Terhadap Waktu yang Dipergunakan dalam Menyampaikan Materi Sumber : Data Diolah (Penulis)

Berdasarkan gambar di atas, $56 \%$ peserta berpendapat bahwa waktu yang dipergunakan dalam menyampaikan materi dalam kegiatan sangat baik, $32 \%$ peserta berpendapat baik, $12 \%$ peserta berpendapat cukup, dan tidak ada yang berpendapat bahwa waktu yang dipergunakan dalam menyampaikan materi dalam kegiatan kurang baik dan sangat 
kurang baik. Dari gambar di atas dapat disimpulkan bahwa mayoritas peserta berpendapat bahwa waktu yang dipergunakan dalam menyampaikan materi dalam kegiatan sangat baik.

\section{Kejelasan Materi Kegiatan}

Pertanyaan ini diberikan untuk mengetahui bagaimana pendapat peserta terhadap kejelasan materi dalam kegiatan. Adapun hasil tanggapan dari peserta seperti gambar berikut.

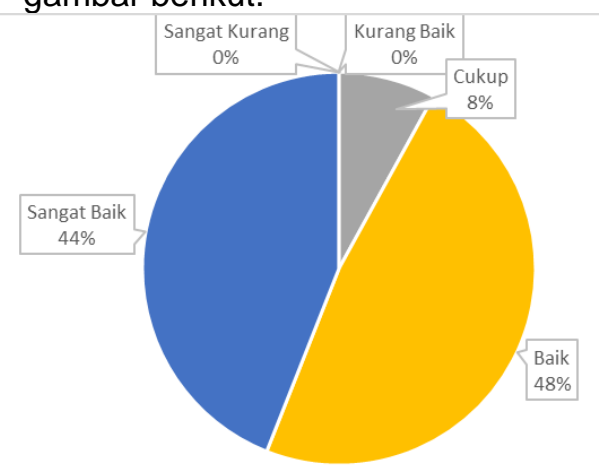

Gambar 7. Tanggapan Peserta Terhadap Kejelasan Materi Kegiatan Sumber : Data Diolah (Penulis)

Berdasarkan gambar di atas, $48 \%$ peserta berpendapat bahwa kejelasan materi dalam kegiatan baik, $44 \%$ peserta berpendapat sangat baik, $8 \%$ peserta berpendapat cukup, dan tidak ada yang berpendapat bahwa kejelasan materi dalam kegiatan kurang baik dan sangat kurang baik. Dari gambar di atas dapat disimpulkan bahwa mayoritas peserta berpendapat bahwa kejelasan materi dalam kegiatan baik.

\section{Minat Terhadap Kegiatan}

Pertanyaan ini diberikan untuk mengetahui bagaimana pendapat peserta terhadap minat terhadap kegiatan. Adapun hasil tanggapan dari peserta seperti gambar berikut.

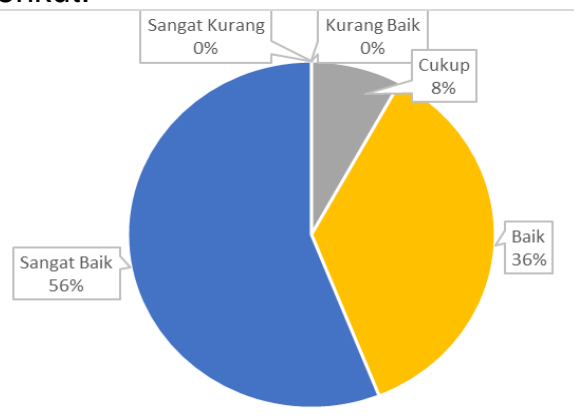

Gambar 8. Tanggapan Peserta Terhadap Minat Terhadap Kegiatan Sumber : Data Diolah (Penulis)
Berdasarkan gambar di atas, $56 \%$ peserta berpendapat bahwa minat terhadap kegiatan sangat baik, 44\% peserta berpendapat baik, $8 \%$ peserta berpendapat cukup, dan tidak ada yang berpendapat bahwa minat terhadap kegiatan kurang baik dan sangat kurang baik. Dari gambar di atas dapat disimpulkan bahwa mayoritas peserta berpendapat bahwa minat terhadap kegiatan sangat baik.

\section{Kepuasan Terhadap Kegiatan}

Pertanyaan ini diberikan untuk mengetahui bagaimana pendapat peserta terhadap kepuasan terhadap kegiatan. Adapun hasil tanggapan dari peserta seperti gambar berikut.

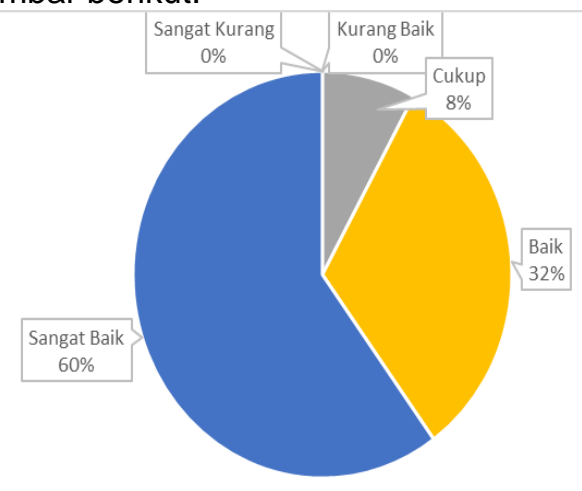

Gambar 9. Tanggapan Peserta Terhadap Kepuasan Terhadap Kegiatan Sumber : Data Diolah (Penulis)

Berdasarkan gambar di atas, $60 \%$ peserta berpendapat bahwa kepuasan terhadap kegiatan sangat baik, 32\% peserta berpendapat baik, $8 \%$ peserta berpendapat cukup, dan tidak ada yang berpendapat bahwa kepuasan terhadap kegiatan kurang baik dan sangat kurang baik. Dari gambar di atas dapat disimpulkan bahwa mayoritas peserta berpendapat bahwa kepuasan terhadap kegiatan sangat baik.

Pelaksanaan kegiatan PKM ini hari Kamis, 28 Oktober 2021. Kegiatan ini dilakukan berupa penyampaian materi tentang Pembukuan Transaksi Keuangan UMKM yang meliputi topik : penjelasan sederhana mengenai pengertian pembukuan, bagaimana bentuk catatan yang baik, contoh bentuk buku catatan keuangan yang sederhana, dan perhitungan laba rugi.

Perincian jadwal kegiatan dan materi dapat dilihat pada tabel berikut: 
Tabel 3. Tabel Perincian Kegiatan PKM dan Materi

\begin{tabular}{|c|c|c|}
\hline Waktu & Kegiatan & $\begin{array}{c}\text { Penyaji/Pelaks } \\
\text { ana }\end{array}$ \\
\hline $\begin{array}{l}09.00- \\
09.30\end{array}$ & $\begin{array}{l}\text { Registrasi } \\
\text { Peserta dan } \\
\text { Pembagian } \\
\text { Materi }\end{array}$ & $\begin{array}{l}\text { Tim Pelaksana } \\
\text { PKM }\end{array}$ \\
\hline $\begin{array}{l}09.30- \\
10.00\end{array}$ & $\begin{array}{l}\text { Penyampaian } \\
\text { Materi } \\
\text { Pembukuan } \\
\text { Transaksi } \\
\text { Keuangan } \\
\text { UMKM } \\
\end{array}$ & $\begin{array}{l}\text { Chairia, S.Ak., } \\
\text { M.Ak. }\end{array}$ \\
\hline $\begin{array}{l}10.00- \\
11.00\end{array}$ & $\begin{array}{lr}\text { Sesi } & \text { Tanya } \\
\text { Jawab } & \text { dan } \\
\text { Diskusi } & \\
\end{array}$ & $\begin{array}{l}\text { Tim Pelaksana } \\
\text { PKM }\end{array}$ \\
\hline $\begin{array}{l}11.00- \\
11.30\end{array}$ & $\begin{array}{ll}\text { Sesi } & \text { Foto } \\
\text { Bersama } & \end{array}$ & $\begin{array}{l}\text { Tim Pelaksana } \\
\text { PKM }\end{array}$ \\
\hline
\end{tabular}

Pelaksanaan kegiatan dengan cara praktek langsung, Tanya jawab, dan diskusi antara sesame peserta dan pemateri. Gambar berikut ini dokumentasi foto pelaksanaan PKM:

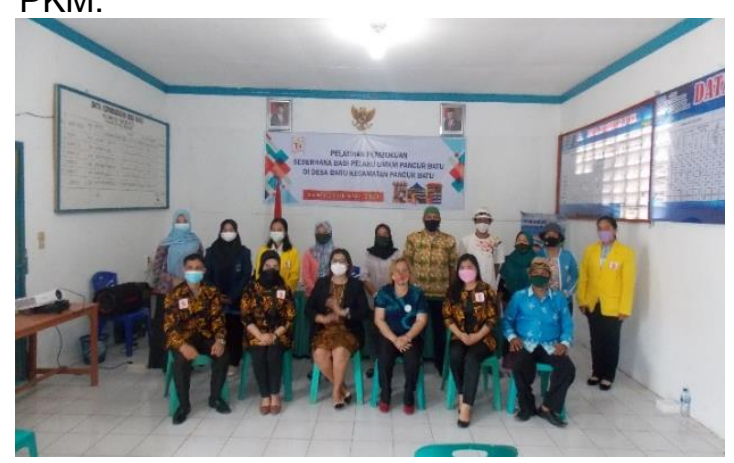

Gambar 10. Pelaksanaan Kegiatan Pengabdian

Sumber : Data Diolah (Penulis)

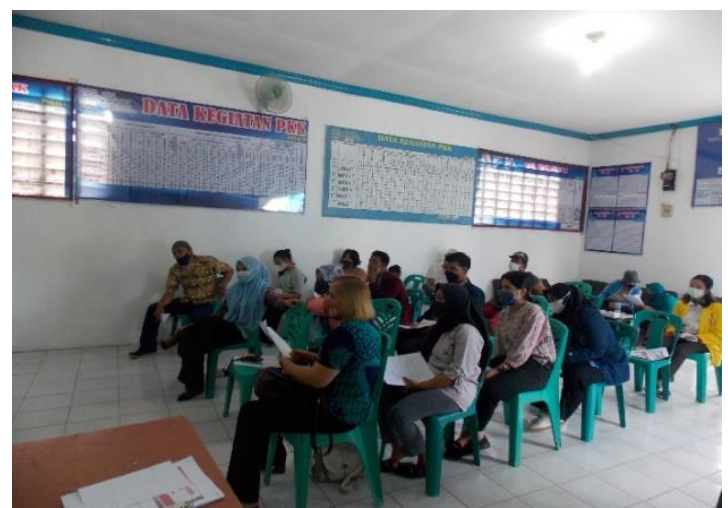

Gambar 11. Sesi Tanya Jawab dan Diskusi Sumber : Data Diolah (Penulis)

\section{SIMPULAN DAN SARAN}

Berdasarkan gambar 2 dapat disimpulkan bahwa mayoritas peserta berpendapat bahwa materi yang disampaikan dalam kegiatan sangat baik. Berdasarkan gambar 3 dapat disimpulkan bahwa mayoritas peserta berpendapat bahwa respon terhadap materi yang disampaikan dalam kegiatan baik. Berdasarkan gambar 4 dapat disimpulkan bahwa mayoritas peserta berpendapat bahwa hubungan materi yang disampaikan dengan kebutuhan dalam kegiatan sangat baik. Berdasarkan gambar 5 dapat disimpulkan bahwa mayoritas peserta berpendapat bahwa pemateri dan teknik penyajian dalam kegiatan sangat baik. Berdasarkan gambar 6 dapat disimpulkan bahwa mayoritas peserta berpendapat bahwa waktu yang dipergunakan dalam menyampaikan materi dalam kegiatan sangat baik. Berdasarkan grafik dapat disimpulkan bahwa mayoritas peserta berpendapat bahwa kejelasan materi dalam kegiatan baik. Berdasarkan gambar 7 dapat disimpulkan bahwa mayoritas peserta berpendapat bahwa minat terhadap kegiatan sangat baik. Berdasarkan gambar 8 dapat disimpulkan bahwa mayoritas peserta berpendapat bahwa kepuasan terhadap kegiatan sangat baik. Berdasarkan gambar 9 dapat disimpulkan bahwa mayoritas peserta berpendapat bahwa kepuasan terhadap kegiatan sangat baik.Setelah dilaksanakannya pengabdian kepada masyarakat ini, kami sudah mencapai tujuan pengabdian yaitu memberi motivasi dan semangat kepada pelaku UMKM untuk melakukan wirausaha, meningkatkan kreativitas dan inovasi para pelaku UMKM, dan memberi pengetahuan tentang pentingnya pencatatan transaksi keuangan melalui pembukuan sederhana.

\section{UCAPAN TERIMAKASIH}

Program Pengabdian Masyarakat ini dapat terlaksana berkat dukungan dan kerjasama dengan LPPM Institut Teknologi dan Bisnis Indonesia (ITB Indonesia) serta dari berbagai pihak, oleh karena itu tim pengabdian menyampaikan terima kasih sedalamdalamnya kepada Rektor ITB Indonesia dan bagian LPPM yang telah memberikan kesempatan untuk melakukan pengabdian pada masyarakat, mahasiswa yang telah bersedia membantu selama pelaksanaan kegiatan pengabdian, Kepala Desa Baru kecamatan Pancur Batu dan peserta pelatihan yang telah mengundang kami untuk melaksanakan kegiatan pengabdian ini.

\section{DAFTAR RUJUKAN}

Arbi, N. (2020). Virus corona: Akankah pembatasan sosial berskala besar tekan penyebaran wabah di Indonesia? Diambil dari

https://www.bbc.com/indonesia/indonesia $-52153187$ 
Hasibuan, R., Swibawa, G., Indriyati, \& Aeny, T. N. (2011). LAPORAN PENGABDIAN KEPADA MASYARAKAT PELATIKAN. (1510210207), 1-19.

Juita, V. (2016). Pemanfaatan Sistem Informasi Akuntansi Pada Usaha Mikro, Kecil, Dan Menengah (Umkm) Sektor Jasa Perdagangan Di Padang, Sumatera Barat. Jurnal Riset Akuntansi Terpadu, 9(1), 120-139.

https://doi.org/10.35448/jrat.v9i1.4291

Kemendikbud. (2021). Program Kreativitas Mahasiswa - Pedoman Umum. In Kewirausahaan (PKM-K) (Vol. 3).

Kesuma, N., Nurullah, A., \& Meirawati, E. (2020). Pendampingan Pencatatan dan Pembukuan Sederhana bagi Orang Pribadi sebagai Pelaku Usaha di Kelurahan Talang Jambe, Kota Palembang. Sricommerce: Journal of Sriwijaya Community Services, 1(2), 101106. https://doi.org/10.29259/jscs.v1i2.18

Lestiani, E., Maryam, S., \& Widayanti, R. (2020). Bongaya Journal of Research in Management. Bongaya Journal of Research in Management, 3(2), 7-13.

Limanseto, H. (2021). UMKM Menjadi Pilar Penting dalam Perekonomian Indonesia. Diambil dari https://ekon.go.id/publikasi/detail/2969/u mkm-menjadi-pilar-penting-dalamperekonomian-indonesia

Nurlida, \& Sinuraya, J. (2020). Potensi UMKM Dalam Menyangga Perekonomian Kerakyatan di Masa Pandemi Covid-19: Sebuah Kajian Literatur. Seminar Akademik Tahunan IImu Ekonomi dan Studi Pembangunan 2020, 73. Diambil dari www.lokadata.beritagar.id

Rahmat, J., \& Suryakancana. (2016). Masalah yang dihadapi Usaha Kecil Menengah di Indonesia. Kajian dan Riset Manajemen Profesional, 2(6), 15-34.

Sembiring, Y., \& Elisabeth, D. M. (2018). Penerapan Sistem Akuntansi Pada Usaha Mikro, Kecil dan Menengah di Kabupaten Toba Samosir. Jurnal Manajemen, 4(2), 89-101. Diambil dari https://eresources.perpusnas.go.id:2089/id/public ations/271129/penerapan-sistemakuntansi-pada-usaha-mikro-kecil-danmenengah-di-kabupaten-toba 